\title{
Investigations of natural attenuation in groundwater near a landfill and implications for landfill post-closure
}

\author{
Daniel Hubé, Laurence Gourcy, Jean-Christophe Gourry, Dominique Guyonnet \\ BRGM, 3 Avenue Claude Guillemin, BP 36009, 45060 Orléans Cédex 2, France
}

The controlled landfill technology is now adopting passive attenuation techniques as an increasing number of landfill sites reach the post-closure phase. During the post-closure phase, landfill operators need to convince environmental authorities that landfills no longer pose a threat to health or the environment. The demonstration of such absence of risk should rely in particular on data collected during environmental monitoring in addition to modelling of possible future evolutions of environmental concentrations. One difficulty that is typically encountered in France is related to the fact that groundwater monitoring systems around landfills are often insufficiently detailed to provide conclusive evidence of natural attenuation mechanisms. This paper presents data on groundwater quality in the vicinity of an old landfill located in a complex aquifer system. While isotopic data suggest a signature of the landfill leachate in the groundwater in the vicinity of the landfill, chemical analyses do not show a strong influence, which could be indicative of natural attenuation mechanisms. However, the complexity of the groundwater system in this area is such that it cannot be excluded that emissions to the groundwater are not being overlooked. Implications of demonstrating natural attenuation during the landfill post-closure phase, with respect to groundwater monitoring, are discussed.

Keywords: Landfill, Groundwater, Natural Attenuation, Isotopes, Monitoring 


\section{Introduction}

The "Controlled Landfill" technology, which emerged in the seventies but only became truly operational in France in the late eighties under the impetus of environmental regulations, is now adopting passive attenuation techniques, as an increasing number of landfill sites reach the post-closure phase. A typical example of such techniques is the use of methane oxidation covers for the passive treatment of residual greenhouse gas emissions (e.g. Scheutz et al., 2009). From an operator's perspective, if a landfill is no longer a source of income, it is highly desirable that it should rapidly cease to be a source of cost. Therefore during the post-closure phase, landfill operators need to convince environmental inspectors that landfills no longer pose a threat to health or the environment.

The demonstration of such absence of risk should rely in particular on data collected from environmental monitoring networks in addition to modelling of possible future evolutions of environmental concentrations. Models for groundwater contaminant transport generally include conservative assumptions, due to the inherent complexity of mechanisms affecting the fate of contaminants in groundwater near landfills. Because conservative assumptions tend to maximise the estimation of risk, it would seem necessary in a context of post-closure risk assessments for decommissioning old landfills, to demonstrate by field data that attenuation mechanisms are at work in the subsurface. Such demonstration has been performed in the past by several researchers. In an extensive review of the biogeochemistry of landfill leachate plumes, Christensen et al. (2001) note that "Heavy metals do not seem to constitute a significant pollution problem at landfills, ..., partly because of strong attenuation by sorption and precipitation.”. Such attenuation mechanisms help explain why groundwater plumes generated by domestic waste landfills are typically much shorter in extent than plumes caused by industrial contamination such as for example chlorinated solvents (i.e., plume lengths on the order of kilometres; McGuire et al., 2004). Hence natural attenuation has been proposed as a remediation strategy for old landfills (e.g. van Vossen et al., 2009; Tuxen et al., 2006; Baun et al., 2003; Christensen et al., 2000, Christensen et al., 1994).

The objective of this project was to examine the potential of several direct and indirect investigation techniques, for evaluating the impact on groundwater of an old non-hazardous waste landfill site and for identifying the possible occurrence of natural attenuation mechanisms. 


\section{Material and Methods}

\section{The landfill site}

The landfill site is located in the central region of France $\left(46^{\circ} 53^{\prime} 13^{\prime \prime} \mathrm{N}, 3^{\circ} 28^{\prime} 51^{\prime \prime} \mathrm{E}\right)$, near the town of La Machine and covers an area of approximately 4 acres. The landfill was in operation during the period from 1974 to 1999 and was therefore not equipped with leachate control barriers such as prescribed by current legislation (OJC, 1999). The site is currently fenced and covered by a thin ( 0.1 to 0.5 meters) layer of earth encroached by a spontaneous vegetation (grass and trees). The waste is therefore very close to ground surface and is even apparent at places. Landfilling activities took place on the site of a pre-existing coal mine that started operation in 1954. Mining activities in the area are far more ancient and can be traced back to the $15^{\text {th }}$ century.

The landfill fills up a thalweg, formerly the bed of a stream (the Judas Stream; Figure 1) which was diverted during the 90's along the northern edge of the landfill. The stream receives water from a small affluent and from resurgences. It flows ENE-WSW and then, $1 \mathrm{~km}$ east of the landfill, turns abruptly southward towards a pond, due to the contact between Carboniferous (to the West) and Triassic (to the East) formations. The area of the landfill is made up of 5 successive plateaus, indicated in Figure 1 as Zones 1 through 5, with weak slopes and therefore poor drainage of rainfall.

The landfill area is located along the Eastern border of a Permo-Carboniferous coal basin, and overlies essentially detrital formations (arkosic sandstones, altered argilites, coal shales). An example of the succession of geologic formations in the near subsurface is provided in Table 1. The coal beds were exploited in the area of the landfill by two mine shafts (indicated in Figure 1 as Shafts 1 and 2), approximately $140 \mathrm{~m}$ in depth and that are now backfilled. Development of subsurface mining activities and subsequent flooding of the mining cavities has probably led to a specific shallow mine aquifer. Towards the east of the site, the Stephanian (Upper Carboniferous) detrital formations come into contact with Triassic formations made of sandy and evaporitic marls.

The hydrogeologic system in the vicinity area of the landfill includes 3 reservoirs, each with its specific water body: the waste body, the underlying Stephanian clayey sandstones and the mining galleries. The waste body is partially permeated by leachate and is in direct contact with the Stephanian sandstones. The 
Stephanian clayey sandstone reservoir has a strongly anisotropic hydraulic conductivity, due to a formation dip of $30^{\circ}$ towards the SSW. It is limited to the East by a NNE-SSW fault which separates it from the Triassic reservoir (Figure 1). Horizontal hydraulic conductivities are estimated to be on the order of $10^{-5}$ to $10^{-6} \mathrm{~m} / \mathrm{s}$, with a strong anisotropy. The dip of the layers favours a direction of flow WNW - ESE. The mining gallery reservoir is poorly known but some indications can be found in reports of past mining activities. It is a confined aquifer, as shown by the presence of resurgences (see Figure 1). The resurgence waters have a high level of dissolved solids, due to the presence of sulphate, a relatively low $\mathrm{pH}$ and a low redox potential. They give rise to red-coloured precipitation at ground surface in the vicinity of the resurgences.

The Bussière water supply well (Figure 1) is located $1.2 \mathrm{~km}$ east of the landfill. It draws water from Triassic formations and is hydraulically independent of the formations potentially influenced by the landfill. Taking into account the elevations of different sources and local structural geology, any influence of the landfill on this water supply well can be ruled out completely.

\section{Geological and geophysical investigations}

Geological and geophysical investigations were performed in the area of the landfill in order to provide information on the potential source of contamination and thus help assess possible attenuation of this source in the vicinity of the landfill. Thirteen trenches were dug with a backhoe directly within the waste mass, in order to characterize the nature of the waste and also to directly determine the depth of the substratum. Eleven piezometers were installed for the sampling of leachate in the waste mass and of groundwater in the vicinity of the landfill. Several geophysical methods; electrical resistivity tomography, electromagnetic resistivity mapping (EM31 and EM34) and self-potential measurements, were used at the landfill surface. Such geophysical methods provide information on resistivity contrasts, indicative of possible contamination of the subsurface by low-resistivity leachate, or on biological activity within the waste body. They also provide useful information on lateral variations of waste thickness. The results must be interpreted carefully however, as they may be influenced by effects such as geological or chemical heterogeneities and it is therefore essential to combine geophysical results with direct observations, obtained in particular from trenches and boreholes. 
Electrical resistivity tomography (e.g. Samouëlian et al., 2005) consists in injecting an electric current via two electrodes planted in the ground and measuring the difference of potential between two other electrodes. The ratio between measured potential and injected current is proportional to electrical resistivity. By performing a large number of measurements with electrodes of varying separation distances, a vertical resistivity profile is constructed.

Self-potential (SP) is a passive geophysical method that consists in measuring the natural electrical potential field generated by several electrokinetic and electrochemical phenomena (Naudet, 2004):

- Electrofiltration. Fluid transport in a porous medium generates an electrical current and therefore an electrofiltration potential that can be measured at ground surface. The difference in potential is proportional to the hydraulic gradient;

- Electrochemical (redox) reactions. A redox potential gradient generates an electrical potential (on the order of $0.5 \mathrm{mV} / \mathrm{mV})$;

- Electrodiffusion. An electrolyte concentration gradient generates a diffusive ion flux, with an electrical potential that is proportional to the logarithm of the electrolyte concentration ratios.

In a landfill environment such as La Machine, the first two phenomena tend to dominate. The contribution of electrodiffusion is weak because spatial variations in electrical conductivity do not exceed on the order of $5 \mathrm{mV}$. On the other hand, because there can be important variations of water levels within the waste, the electrofiltration component may be significant. Also, biological activity tends to generate spatial differences in redox potential, which in turn generates an electrical potential. It is this potential that is measured at ground surface as an indirect indicator of biological activity within the waste mass and hence of its relative biogeochemical (in)stability. Two SP campaigns were performed: one along the same profile as the electrical tomography and another over the entire area of the landfill.

\section{Geochemical analyses}

Geochemical analyses were performed on samples collected within the landfill, on groundwater samples collected in piezometers and from the resurgences and the surface waters indicated in Figure 1. Nonconservative parameters (dissolved oxygen, $\mathrm{pH}$, Eh, temperature, electrical conductivity) were measured directly on site, immediately following sampling. Samples for major ion and trace inorganic element analyses, were filtered in the field $(0.45 \mu \mathrm{m}$ filter) and acidifed (for cation analyses). Analyses also 
included nitrogen species, COD and BOD. Sediments collected in the Judas Stream, up and down-gradient from the landfill, were also analyzed for trace metals, following acid attack by regal water.

Isotopic analyses were performed on water samples (leachates, groundwater and resurgences) for tritium $\left({ }^{3} \mathrm{H},{ }^{2} \mathrm{H} /{ }^{1} \mathrm{H}\right)$ and carbon isotopes $\left({ }^{13} \mathrm{C} /{ }^{12} \mathrm{C}\right.$ ratios). Hydrocarbon species (volatile halogenated compounds; VHCs, volatile aromatic compounds; VACs) were measured on selected samples, using gas phase chromatography coupled with mass spectrometry. Certain pharmaceutical molecules were also analyzed (Atenolol, Metoprolol, Propanolol, etc.).

\section{Results}

\section{Results of backhoe investigations}

The backhoe trenches (noted $\operatorname{Tr} 1-\operatorname{Tr} 13$ in Figure 1), combined with information from piezometer boreholes, provide information on waste thicknesses in the different Zones and on the nature of landfilled waste. The waste body is 1 to 6 meters thick, following the Zone (note that Zone 1 was not accessible with the backhoe). Zone 2 contains, from bottom to top, 1 to 3 meters of non-hazardous industrial waste (large rubber straps, cables, etc.), some old metal drums with locally smells of hydrocarbons. These wastes are overlain by 2 meters of municipal solid waste with a high proportion of plastics mixed with gravel, vegetable waste, scrap and demolition waste. Zone 3 is made of 4 to 5 meters of biodegraded municipal solid waste (plastic bags, glass, paper, cardboard, etc.) with locally traces of combustion. Zone 4 is made up of gravel and inert demolition waste. In Zone 5, excavations showed primarily municipal solid waste (plastic, glass, remains of organic matter) but also some pharmaceutical waste (tablets and bottles) mixed with local schistous and sandstone material. The backhoe and borehole investigations allowed the collection of samples of the substratum underlying the waste, made essentially of sandy clay. This sandy clay separates the waste from the more permeable Stephanian clayey sandstones.

\section{Piezometry}

Figure 2 shows piezometric levels at the La Machine landfill in March 2007, during a period of high phreatic level, while Figure 3 shows piezometric levels in September 2008; i.e., during a low phreatic level. These maps illustrate that the hydraulic behaviour of the landfill is very different during periods of high and low phreatic levels. During the period of low phreatic level (Figure 3), leachate flows towards the 
East along the axis of the landfill. While during the period of high phreatic level (Figure 2), there is formation of a piezometric dome within the landfill, approximately centered on Zone 3. During this period, the elevation of the Judas stream is lower than that of the piezometric dome and therefore the stream may act as a drain for leachate. This seasonal difference gives rise to a conceptual hydrologic model that is presented in the last section. There remains uncertainty with respect to the relationship between the mine gallery reservoir and the Stephanian sandstone and waste reservoirs. It is possible that during periods of high phreatic levels, when hydrostatic pressure is on the order of 8-9 meters with respect to the elevation of the mine resurgences, drainage from the waste could infiltrate the mine reservoir.

\section{Results of geophysical investigations}

Results of resistivity measurements, confirmed by electromagnetic mapping (EM31 and EM34) show in Figure 4 that resistivity within Zones 2 and 3, which is the heart of the landfill, is much lower than in other areas. This is consistent with the presence of leachate in these zones, with high total dissolved solids (TDS). But it can also be related to heterogeneity within the waste and the presence of metallic waste; old vehicle debris for example as suggested by the trenches. The sharp resistivity contrast observed at 15-20 meters depth does not correspond to the limit with the substratum, since the backhoe investigations showed that the waste is only 5 to 6 meters depth maximum. It is suggested therefore that the low resistivities measured at greater depth are caused by the infiltration of leachate into the substratum. We see in Figure 4 that there is an anomaly of low resistivity below 30 meters depth, between points $250 \mathrm{~m}$ and $300 \mathrm{~m}$ along the measured profile. This could be an indication of preferential infiltration of leachate but could also be due to an abrupt change in the underlying rock (a fault).

The self-potential method, which is related to electroredox effects, did not show significant variations within the landfill. This is interpreted as an effect of the waste's level of maturity, with reduced biodegradation activity. The bulk of the waste body has a similar redox state, or at least spatial variations are not sufficient to be detected by the method used. An exception is Zone 3, which showed a strongly negative self-potential effect (Hubé et al., 2009), suggesting more reducing conditions in this zone. This is consistent with measurements, using Dräger-type probes, of landfill gas concentrations at the surface of the waste that showed higher levels in Zone 3 than in Zone 2 (Hubé et al., 2009).

\section{Results of geochemical investigations}


Tritium analyses show a signature of the landfill in groundwater located down-gradient from the landfill and also in the pond (Figure 1). While groundwater with no influence of the landfill has tritium concentrations below 7 TU (Tritium Units), leachates collected within the landfill show concentrations between 30 and 190 TU. Such enrichment is well known in MSW landfills (e.g. Robinson and Gronow, 1996) and can be explained by the presence of paints, watches and other luminescent products. Waters with ${ }^{3} \mathrm{H}$ concentrations between 11 and $25 \mathrm{TU}$ are found down-gradient from the landfill, in PZ3 and in the pond, suggesting an influence of the landfill. Based on historical tritium concentrations in rainwater, it can be estimated that the average residence time of groundwater at locations PZ7 or Well B is on the order of 40 years.

Carbon isotopic ratios were found to be an interesting marker of landfill influence. The ${ }^{13} \mathrm{C} /{ }^{12} \mathrm{C}$ ratios for uninfluenced groundwater are typically between -15 and $-12 \%$ (Vogel and Ehhalt, 1963) as shown at points Sup, PZ1, PZ2 and PZ7. Measurements show an enrichment of the heavy carbon isotope, due to the production of methane. This enrichment is particularly noticeable (Figure 5) in the leachate samples (dots), while samples from PZ3 and the pond for instance show intermediate ratios. Res 3 is showing more negative values due to the influence of $\delta^{13} \mathrm{C}$ in soil $\mathrm{CO}_{2}$ (-25\% in temperate regions). Coal bed influence should also lead to a more negative ${ }^{13} \mathrm{C} /{ }^{12} \mathrm{C}$ ratio of groundwater bicarbonates (not seen here).

Measurements of $\mathrm{pH}$ and $\mathrm{Eh}$ in groundwater, surface water and leachate from the different zones (Table 2 and additional data in Hubé et al., 2009), show a shift from oxidizing (Eh $\approx 450$ to $520 \mathrm{mV}$ ) and slightly acid $(\mathrm{pH} \approx 6.5-7)$ conditions upstream from the landfill, to more reducing (Eh $\approx 100$ to $180 \mathrm{mV}$ ) and basic ( $\mathrm{pH} \approx 7.5$ to 9 ) conditions within the landfill premises, while oxidizing and near-neutral $\mathrm{pH}$ conditions are restored downstream from the landfill. For example the $\mathrm{pH}$ and Eh of groundwater from piezometer PZ1 (upstream from the landfill), the stream (Sup) and the pond (downstream) are practically identical (Eh between 480 and $520 \mathrm{mV}$ and $\mathrm{pH}$ between 6.4 and 6.8; see point locations in Figure 1). The waters from the mine resurgence noted Res 2 in Figure 1 is characterized by relatively high sulfate concentrations, while mine resurgence Res1 shows high levels of iron. This illustrates the influence of local lithology and complicates the use of $\mathrm{Fe}$ as a tracer of landfill influence.

Major cation and anion analyses tend to distinguish between three major groundwater "facies":

(i) $\mathrm{Na}+\mathrm{K}, \mathrm{HCO}_{3}$ leachates within the waste body,

(ii) $\mathrm{Cl}, \mathrm{SO}_{4}, \mathrm{Ca}, \mathrm{Mg}$ groundwater close to the landfill (PZ1, PZ3, PZ4, Res2, Res3), 
(iii) $\mathrm{Ca}, \mathrm{Mg}, \mathrm{HCO}_{3}$ groundwater further away from the landfill (PZ7, PZ2, Well B, Res1).

Ammonia $\left(\mathrm{NH}_{4}\right)$ may reach $1300 \mathrm{mg} / \mathrm{L}$ in leachate collected from the landfill. It is found however at low concentrations in groundwater immediately down-gradient (PZ3, PZ4), with concentrations on the order of $2.4 \mathrm{mg} / \mathrm{L}$ or below detection limits. Nitrate concentrations remained low in the groundwater (a maximum of $8.9 \mathrm{mg} / \mathrm{L}$ is measured in PZ1, which is located up-gradient from the landfill). COD values in the leachates are in the range of 300-3000 $\mathrm{mg} / \mathrm{L}$ while in the groundwater, COD values are in the range of 2-70 $\mathrm{mg} / \mathrm{L}$ and while BOD is below detection limit.

Comparison of major ions in surface waters collected upstream and downstream from the landfill (Figure 6) show an increase of dissolved constituents. In this Figure, results obtained on a sample from the Bussière Well, which is by no means influenced by the landfill, are shown for comparative purposes to illustrate the potential influence of local geology on measured water concentrations. Trace metal concentrations in surface waters (Figure 7) do not suggest a significant influence of the landfill, since concentrations in water samples taken upstream from the landfill (Sup) are comparable to those collected downstream. This is also the case in the sediments collected from the Judas Stream upstream and downstream from the landfill (Figure 8). Worth noting are the relative As and $\mathrm{Zn}$ anomalies (on the order of $100 \mathrm{mg} / \mathrm{Kg}$ ) measured in the upstream sample (Sup, i.e., uninfluenced by the landfill).

Figure 9 illustrates the increase of dissolved major ions in the leachate of PZ5, which is located directly within the landfill and in piezometers PZ3 and PZ4 located downgradient, compared to PZ7 which is completely out of the landfill's area of influence. Again, local water-rock interaction might explain part of the increase, as shown by concentrations in water from the Bussière Well. Worth noting is the total lack of nitrogen species in piezometer PZ4 (Table 2), while as mentioned above ammonia concentrations in the landfill are up to $1300 \mathrm{mg} / \mathrm{L}$ (borehole F2; Figure 1). The increase of dissolved constituents is also seen in trace metal concentrations (Figure 10). In this Figure, zinc concentrations in the Bussière Well could be related to well tubing. The arsenic concentration in PZ4 is at the limit with respect to water intended for human consumption (10 $\mu \mathrm{g} / \mathrm{L}$; OJC, 1998). Considering the natural presence of As in the local formations, these concentrations could be related to an influence of lower redox conditions in the vicinity of the landfill, which increases arsenic solubility. Trace elements were higher in the leachates (Cr up to 38,7 $\mu \mathrm{g} / \mathrm{L}, \mathrm{Cu}$ up to $23 \mu \mathrm{g} / \mathrm{L}, \mathrm{Pb}$ up to $35.2 \mu \mathrm{g} / \mathrm{L}, \mathrm{Cd}$ up to $2.1 \mu \mathrm{g} / \mathrm{L}$ ) than in the surrounding groundwater where for $\mathrm{Pb}, \mathrm{Cr}$ and $\mathrm{Cd}$, values are below or close to detection limits. This suggests attenuation mechanisms 
such as for example co-precipitation with carbonates, as speciation calculations show that the leachates are oversaturated with respect to carbonate minerals (calcite, aragonite, magnesite, ...).

Hydrocarbon analyses (Total hydrocarbons, BTEXs, VHCs and VACs) showed highest concentrations in leachates collected at point F2 (sum of BTEXs and VACs $>93 \mu \mathrm{g} / \mathrm{L}$ ), with Xylenes as the dominant species. On the other hand VHCs were all below detection limits in the leachates. Analyses results for organic compounds in the groundwater in the vicinity of the landfill were all below detection limits, with the notable exception of vinyl chloride $(2 \mu \mathrm{g} / \mathrm{L})$ and Cis 1,2-dichloroethylene $(5 \mu \mathrm{g} / \mathrm{L})$ which were detected at one resurgence (Res1; Figure 1). This resurgence is very close to the old mining facility. It is reminded that vinyl chloride is a degradation product of trichloroethylene and tetrachloroethylene. Analyses of pharmaceutical molecules in leachate samples from PZ5 were all below detection limits.

\section{Discussion and conclusions}

The investigation of the La Machine landfill illustrates the complexity of the interaction between the landfill and its environment. Piezometric measurements performed at different times of the year (see also Hubé et al., 2009) show that the landfill has a transient hydrologic behaviour as illustrated in Figure 11. During the dry period, the directions of water flow are from the landfill vicinity towards the waste body, while during the winter period, a piezometric mound forms within the waste body and flow directions are divergent towards the vicinity. Therefore during the phreatic high, one can expect emission of leachate over a significant portion of the base of the landfill. As seen above, considering the elevation of the Judas Stream, leachate may also flow into the stream, while during the period of low phreatic level, the Judas Stream may contribute flow to the waste. In both cases, there is an accumulation of leachate along the axis of the landfill, which corresponds to the old thalweg of the Judas stream.

The geological, geophysical and geochemical investigations performed provide indications of an influence of the landfill on groundwater and surface water in its vicinity, but without showing significant increases in pollutant loads. In particular, no significant influence of the landfill on groundwater or surface water is observed for heavy metals, chemical oxygen demand, nitrogen species, hydrocarbon species or pharmaceutical molecules. On the other hand, isotopic ratios (in particular tritium and carbon isotopes) show a signature of the landfill in waters sampled in its vicinity. This contrast between isotopic and 
chemical signatures could be an indication of attenuation mechanisms. However, due to the relative complexity of the hydrologic system, this hypothesis should be verified by further investigations, in particular additional piezometers downgradient from the landfill, or by examining the soil matrix in the immediate vicinity of the landfill, in order to identify precipitations that might explain low levels of heavy metals in the groundwater. A difficulty of the latter approach however, is the heterogeneity of the soil matrix which hampers the detection of such precipitates. Tracer tests could also be performed in the landfill area, but slow groundwater flow velocities would make such tests very difficult to implement.

In addition to the transient nature of flow in the vicinity of the La Machine landfill, interpretation of the local hydrology is further complicated by the presence of mining shafts and deep water circulations. In such a context, the network of piezometers that served in this investigation, although much more detailed that networks typically used in practice in France for landfill groundwater monitoring, is not sufficient to ensure that landfill emission to the groundwater are not being overlooked. The shortcomings of groundwater monitoring networks are a major difficulty with respect to the identification of natural attenuation mechanisms during the post-closure phase. Typical groundwater monitoring networks are not well suited for demonstrating the occurrence of attenuation mechanisms in the vicinity of landfills. This is particularly the case when groundwater monitoring networks are designed with reference to minimal requirements of the Landfill Directive (OJC, 1999), according to which a network should include (Annex III) "... at least one measuring point in the groundwater inflow region and two in the outflow region." Data collected from a monitoring system designed according to such minimal requirements will be unlikely to convince environmental authorities of the reality of the absence of risk. For example, three monitoring points may define a plane, but as was the case in the study presented herein, the groundwater table is much more complex than a plane, due in particular to groundwater mounding within the landfill or to aquifer heterogeneity. Therefore flow directions are rarely uni-directional and a minimal-specification monitoring system is likely to miss contaminant fluxes. Obviously, the balance between the adequate number of monitoring points and the number that is economically feasible will depend strongly on local context.

When natural attenuation is used as a management strategy for contaminated sites, the appropriate concept is MNA (Monitored Natural Attenuation; Wiedemeier et al., 1995; Barker et al., 1987), implying that adequate monitoring of natural processes is the key issue. As pointed out by Yenigül et al. (2005), 
groundwater monitoring networks around landfills are usually insufficient to clearly demonstrate the occurrence of natural attenuation mechanisms. Such conclusions are substantiated by Christensen et al.. (2000) who note that the introduction of natural attenuation as a remediation method for landfill leachate plumes is complicated by the fact that "the large size of landfills, the uncertainty about the local hydrogeology; the possibility of several plumes, and the variety of pollutants involved, make investigations costly". However, as noted by the same authors, few alternatives exist, since the costs involved in actually removing the waste and hauling it to an incineration plant or to another landfill may be excessive.

An alternative for convincing environmental authorities of the absence of risk, which is often favoured by consulting companies, is to rely on model calculations. However, true attenuation is very difficult to model convincingly in a purely predictive mode. For instance, for inorganic pollutants such as heavy metals, existing models often address liquid-solid pollutant partitioning using equilibrium partitioning coefficients (Kds), thereby introducing a retardation effect with respect to pollutant migration, but no immobilization effects associated with pollutant co-precipitation or with irreversible sorption processes. This is illustrated for example in Fernandes et al. (1996) who modelled the impact of a landfill on a marshland environment and who concluded that "modelling results indicate that marshland soil has the capacity to substantially retard the migration of several contaminant species typically found in landfill leachate". It is unlikely that environmental authorities in charge of landfill post-closure will be satisfied with a mere "retardation" of pollutants since such a mechanism does not address the public concern regarding landfills being potential "time bombs". It is therefore anticipated that with the increasing number of landfills reaching post-closure phase, there will be a renewed interest in hydrogeological investigations aimed at demonstrating the occurrence of attenuation mechanisms in the vicinity of the landfills.

\section{Acknowledgements}

We would like to thank David Cazaux for his contribution to the STOCKINOV project, which was supported by BRGM's Research Division. We are also grateful for the comments and corrections of an anonymous reviewer. 


\section{References}

Barker, J.F., Patrick, G.C., Major. D. (1987) Natural Attenuation of Aromatic Hydrocarbons in a Shallow Sand Aquifer. Ground Water Monitoring Review, 7(1), 64-71.

Baun, A., Reitzel, L.A., Ledin, A., Christensen, T.H., Bjerg, P.L. (2003) Natural attenuation of xenobiotic organic compounds in a landfill leachate plume (Vejen, Denmark). Journal of Contaminant Hydrology, 65, 269-291.

Christensen, T.H., Bjerg, P.L., Kjeldsen, P. (2000) Natural attenuation: a feasible approach to remediation of groundwater pollution at landfills? Ground Water Monitoring Review, Winter 2000, 69-77.

Christensen, T.H., Kjeldsen, P., Albrechtsen, H.J., Heron, G., Nielsen, P.H., Bjerg, P.L., Holm, P.E. (1994) Attenuation of landfill leachate pollutants in aquifers. Critical Reviews in Environmental Science and Technology, 24(2): 119-202.

Fernandes, L., Warith, M.A., La Forge, F. (1996) Modelling of contaminant transport within a marshland environment. Waste Management, 16(7), 649-661.

Hubé, D., Gourcy, L., Gourry, J.-C. (2009) Site de l'ancienne décharge de La Machine (58) : Contributions des investigations directes et indirectes à la compréhension du système hydrogéologique du site de la décharge de La Machine. "La Machine (58) old landfill site: contributions of direct and indirect investigations to the comprehension of the hydrogeological system". Final BRGM Report RP-57407FR, 230 pp. (In French).

McGuire, T., Newell, C.J., Looney, B.B., Vangelas, K.M., Sink, C.H. (2004) Historical analysis of monitored natural attenuation: a survey of 191 chlorinated solvent sites and 45 solvent plumes. Remediation, Winter 2004.

Naudet, V. (2004) Les méthodes de résistivité électrique et de potentiel spontané appliqués aux sites contaminés. "Application of resistivity and self-potential methods to contaminated sites". Ph.D. Thesis of the University of Aix-Marseille III. 204 pp. (In French).

OJC (1999) Council Directive 1999/31/EC of 26 April 1999 on the landfill of waste. Official Journal of the European Communities. L182, 19 pp. 
OJC (1998) Council Directive 98/83/EC of 3 November 1998 on the quality of water intended for human consumption. Official Journal of the European Communities. L 330, 23 pp.

Robinson, H.D., Gronow, J. (1996) Tritium levels in leachates and condensates from domestic wastes in landfill sites. Journal of the Chartered Institution of Water and Environmental Management, 10(6), 391-398.

Samouëlian, A., Cousina, I., Tabbagh, A., Bruand, A., Richard, G. (2005) Electrical resistivity survey in soil science: a review. Soil \& Tillage Research, 83, 173-193.

Scheutz, C., Kjeldsen, P., Bogner, J., de Visscher, A., Gebert, J., Hilger, H., Huber-Humer, M., Spokas, K. (2009) Microbial methane oxidation processes and technologies for mitigation of landfgill gas emissions. Waste Management \& Research, 27, 409-455.

Tuxen, N., Albrechtsen, H.J., Bjerg, P. (2006) Identification of a reactive degradation zone at a landfill leachate plume fringe using high resolution sampling and incubation techniques. Journal of Contaminant Hydrology, 85, 179-194.

Van Vossen, W., Olie, F., Peperkamp, H., Folmer, D.T. (2009) New and practical approach for sustainable emisión reduction of closed landfills base don natural biochemical processes: results of a full scale birreactor Project at the landfill Vlagheide in Shijndel (NL). In: Proceedings Sardinia 2009; Twelfth International Waste Management and Landfill Symposium, S. Margherita di Pula, Cagliary, Italy; 5-9 October 2009. CISA Publisher, Italy.

Vogel, J.C., Ehhalt, D. (1963) The use of carbon isotopes in groundwater studies. In: Radioisotopes in Hydrology, IAEA, Vienna, pp. 383-395.

Wiedemeier, T., Wilson, J.T., Kampbell, D.H., Miller, R.N., Hansen, J.E. (1995) Technical protocol for implementing intrinsic remediation with long-term monitoring for natural attenuation of fuel contamination dissolved in groundwater. Volume I. Air Force Center for Environmental Excellence. San Antonio,, Texas: Technology Transfer Division, Brooks Air Force Base.

Yenigül, N.B., Elfeki, A.M., Gehrels, J.C., van den Akker, C., Hensbergern, A.T., Dekking, F.M. (2005) Reliability assessment of groundwater monitoring networks at landfill sites. Journal of Hydrology, 308, 1-17. 
Table 1: Lithology of borehole PZ7

\begin{tabular}{cc}
\hline Depth $(\mathrm{m})$ & Lithology \\
\hline $0.0-0.3$ & Vegetable earth \\
$0.3-1$ & Red clay \\
$1-10$ & Altered sandstone \\
$10-12$ & Sandy clay \\
$12-16$ & Grey clay \\
$16-18$ & Clayey sandstone \\
$18-28$ & Grey sandstone \\
$28-30$ & Clayey sandstone \\
$30-32$ & Altered sandstone \\
\hline
\end{tabular}


Table 2: Results of water sample analyses. Detection limits (DL) are in italics

\begin{tabular}{|c|c|c|c|c|c|c|c|c|c|c|c|c|c|}
\hline & $\begin{array}{l}\text { Temp } \\
{ }^{\circ} \mathrm{C}\end{array}$ & $\mathrm{pH}$ & $\begin{array}{l}\text { Eh } \\
\mathrm{mV}\end{array}$ & $\begin{array}{l}\text { Cond } \\
\mu \mathrm{S} . \mathrm{cm}^{-1}\end{array}$ & $\begin{array}{l}\mathbf{C a} \\
\mathrm{mg} . \mathrm{l}^{-1}\end{array}$ & $\begin{array}{l}\mathbf{M g} \\
\text { mg. } \text { l }^{-1}\end{array}$ & $\begin{array}{l}\mathbf{N a} \\
\mathrm{mg} \cdot \mathrm{l}^{-1}\end{array}$ & $\begin{array}{l}\mathbf{K} \\
\text { mg. } .^{-1}\end{array}$ & $\begin{array}{l}\mathbf{N H}_{4} \\
\text { mg. } .^{-1}\end{array}$ & $\begin{array}{l}\mathbf{H C O}_{3} \\
\mathrm{mg} \cdot \mathrm{l}^{-1}\end{array}$ & $\begin{array}{l}\mathbf{C l} \\
\mathrm{mg} . \mathrm{l}^{-1}\end{array}$ & $\begin{array}{l}\mathbf{S O}_{4} \\
\text { mg. } .^{-1}\end{array}$ & $\begin{array}{l}\mathrm{NO}_{3} \\
\text { mg. } l^{-1}\end{array}$ \\
\hline & & & & & 0.5 & 0.5 & 0.5 & 0.5 & 2 & 5 & 0.5 & 0.5 & 0.5 \\
\hline Sup & 5.3 & 6.8 & 505.8 & 145.3 & 18.1 & 3.0 & 5.7 & 4.9 & $<\mathrm{DL}$ & 40.0 & 7.7 & 21.0 & 6.80 \\
\hline Saf & 8.0 & 7.8 & 350.9 & 71.8 & 5.4 & 1.9 & 4.3 & 2.0 & $<\mathrm{DL}$ & 13.0 & 7.5 & 11.0 & $<\mathrm{DL}$ \\
\hline Res1 & 11.9 & 6.9 & 239.1 & 441.0 & 47.0 & 29.0 & 4.6 & 5.0 & $<\mathrm{DL}$ & 282.0 & 5.3 & 8.0 & $<\mathrm{DL}$ \\
\hline Res2 & 12.0 & 6.8 & 331.0 & 809.0 & 58.6 & 57.0 & 26.0 & 14.0 & $<\mathrm{DL}$ & 183.0 & 51.0 & 204.0 & 2.30 \\
\hline Res3 & 7.8 & 6.0 & 431.0 & 39.3 & 1.5 & 1.2 & 2.5 & 1.3 & $<\mathrm{DL}$ & 4.0 & 3.6 & 8.0 & $<\mathrm{DL}$ \\
\hline Sdo & 6.2 & 8.3 & 371.2 & 603.0 & 68.6 & 13.3 & 15.0 & 23.0 & 9.9 & 214.0 & 22.4 & 95.0 & 2.70 \\
\hline Pond & 5.2 & 6.6 & 487.9 & 480.0 & 46.8 & 24.0 & 13.0 & 10.0 & 2.2 & 133.0 & 24.9 & 98.0 & 2.50 \\
\hline PZ1 & 10.9 & 6.4 & 472.8 & 252.0 & 16.1 & 14.9 & 9.5 & 4.2 & $<\mathrm{DL}$ & 41.0 & 17.6 & 50.0 & 8.90 \\
\hline PZ3 & 11.2 & 6.9 & 272.6 & 1242.0 & 70.0 & 50.0 & 79.0 & 13.0 & 2.4 & 33.0 & 230.0 & 113.0 & $<\mathrm{DL}$ \\
\hline PZ4 & 10.7 & 7.2 & 333.0 & 2230.0 & 195.0 & 274.0 & 68.0 & 25.0 & $<\mathrm{DL}$ & 683.0 & 73.1 & 753.0 & $<\mathrm{DL}$ \\
\hline $\mathrm{F} 2$ & 15.8 & 9.0 & 163.3 & 13870.0 & 49.1 & 40.0 & 1219.0 & 1049.0 & 1300.0 & 6985.0 & 1190.0 & 34.0 & $<\mathrm{DL}$ \\
\hline PZ5 & 13.8 & 6.9 & & 2890.0 & 162.1 & 43.9 & 108.2 & 122.1 & 141.7 & 1393 & 103.8 & 9.8 & $<\mathrm{DL}$ \\
\hline PZ7 & 11.8 & 7.8 & & 400.0 & 36.8 & 15.7 & 10.6 & 7.1 & 0.3 & 176 & 12.5 & 22.5 & 5.3 \\
\hline Bussière & 14.3 & 7.1 & & 552.0 & 81.6 & 7.6 & 18.5 & 27.9 & $<\mathrm{DL}$ & 238 & 12.3 & 65.1 & 33.5 \\
\hline \multicolumn{14}{|l|}{ Well } \\
\hline & $\mathrm{SiO} 2$ & As & $\mathrm{Ba}$ & $\mathrm{Cd}$ & Co & $\mathrm{Cr}$ & $\mathrm{Cu}$ & $\mathrm{Fe}$ & $\mathbf{L i}$ & Mn & $\mathbf{N i}$ & $\mathrm{Zn}$ & $\mathrm{Pb}$ \\
\hline & $\mathrm{mg} \cdot \mathrm{l}^{-1}$ & $\mu \mathrm{g} . \mathrm{l}^{-1}$ & $\mu \mathrm{g} \cdot \mathrm{l}^{-1}$ & $\mu \mathrm{g} . \mathrm{l}^{-1}$ & $\mu \mathrm{g} . \mathrm{l}^{-1}$ & $\mu \mathrm{g} \cdot \mathrm{l}^{-1}$ & $\mu \mathrm{g} \cdot \mathrm{l}^{-1}$ & $\mathrm{mg} . \mathrm{l}^{-1}$ & $\mu \mathrm{g} \cdot \mathrm{l}^{-1}$ & $\mu \mathrm{g} \cdot \mathrm{l}^{-1}$ & $\mu \mathrm{g} \cdot \mathrm{l}^{-1}$ & $\mu g .1^{-1}$ & $\mu \mathrm{g} \cdot \mathrm{l}^{-1}$ \\
\hline & 0.5 & 0.05 & 100 & 0.1 & 0.5 & 0.5 & 0.3 & 0.01 & 1 & 1 & 0.5 & 2 & 0.1 \\
\hline Sup & 13.35 & 1.9 & $<\mathrm{DL}$ & $<\mathrm{DL}$ & $<\mathrm{DL}$ & $<\mathrm{DL}$ & 2.3 & 34.5 & 6.4 & 5.6 & 2.5 & 7.4 & 0.2 \\
\hline Saf & 11.62 & 0.6 & $<\mathrm{DL}$ & 0.2 & 0.6 & $<\mathrm{DL}$ & 0.9 & 48.3 & 6.9 & 31.0 & 4.5 & 6.3 & 0.2 \\
\hline Res1 & 13.35 & 38.8 & 1072.0 & $<\mathrm{DL}$ & 0.9 & $<\mathrm{DL}$ & 0.8 & 10748.0 & 55.0 & 801.0 & 2.0 & 0.8 & $<\mathrm{DL}$ \\
\hline Res2 & 11.05 & 2.5 & $<\mathrm{DL}$ & 0.5 & 10.2 & $<\mathrm{DL}$ & 1.6 & 783.0 & 44.0 & 1336.0 & 25.0 & 17.0 & 0.1 \\
\hline Res3 & 1.57 & 0.3 & $<\mathrm{DL}$ & 0.2 & $<\mathrm{DL}$ & $<\mathrm{DL}$ & 2.3 & 55.6 & 7.5 & 29.0 & 5.3 & 5.7 & 0.1 \\
\hline Sdo & 12.86 & 2.0 & $<\mathrm{DL}$ & 0.2 & 2.2 & 0.6 & 3.9 & 173.6 & 53.0 & 450.0 & 7.0 & 12.0 & 0.1 \\
\hline Pond & 9.89 & 2.0 & $<\mathrm{DL}$ & 0.1 & 3.6 & $<\mathrm{DL}$ & 2.0 & 365.0 & 31.0 & 667.0 & 9.0 & 6.7 & 0.1 \\
\hline PZ1 & 12.12 & 0.9 & $<\mathrm{DL}$ & 0.2 & 1.0 & $<\mathrm{DL}$ & 1.1 & 38.7 & 28.0 & 792.0 & 3.2 & 5.5 & 0.1 \\
\hline PZ3 & 10.39 & 249.0 & 101.0 & $<\mathrm{DL}$ & 0.6 & 0.8 & 9.3 & 38368.0 & 114.0 & 2799.0 & 7.1 & 1.7 & 0.1 \\
\hline PZ4 & 10.47 & 14.0 & $<\mathrm{DL}$ & 0.4 & 6.5 & $<\mathrm{DL}$ & 2.9 & 1674.0 & 482.0 & 520.0 & 19.9 & 5.4 & 0.4 \\
\hline $\mathrm{F} 2$ & 20.44 & 42.8 & 177.0 & 2.1 & 61.6 & 38.7 & 23.0 & 5136.0 & 155.0 & 181.3 & 156.0 & 228.0 & 35.2 \\
\hline PZ5 & 23.3 & 88 & 359 & $<\mathrm{DL}$ & 63.5 & 3.8 & 1.3 & 16.5 & 60.1 & 6554 & 35.4 & 9.1 & 0.3 \\
\hline PZ7 & 11.9 & 3.16 & 172 & 0.06 & 3.5 & 0.2 & 2.4 & 0.18 & 42 & 265 & 9.7 & 13.8 & 0.2 \\
\hline $\begin{array}{l}\text { Bussière } \\
\text { Well }\end{array}$ & 9.3 & 1.16 & 55 & 0.07 & $<\mathrm{DL}$ & 0.7 & 0.4 & $<\mathrm{DL}$ & 1.9 & $<\mathrm{DL}$ & $<\mathrm{DL}$ & 44.6 & 0.1 \\
\hline
\end{tabular}




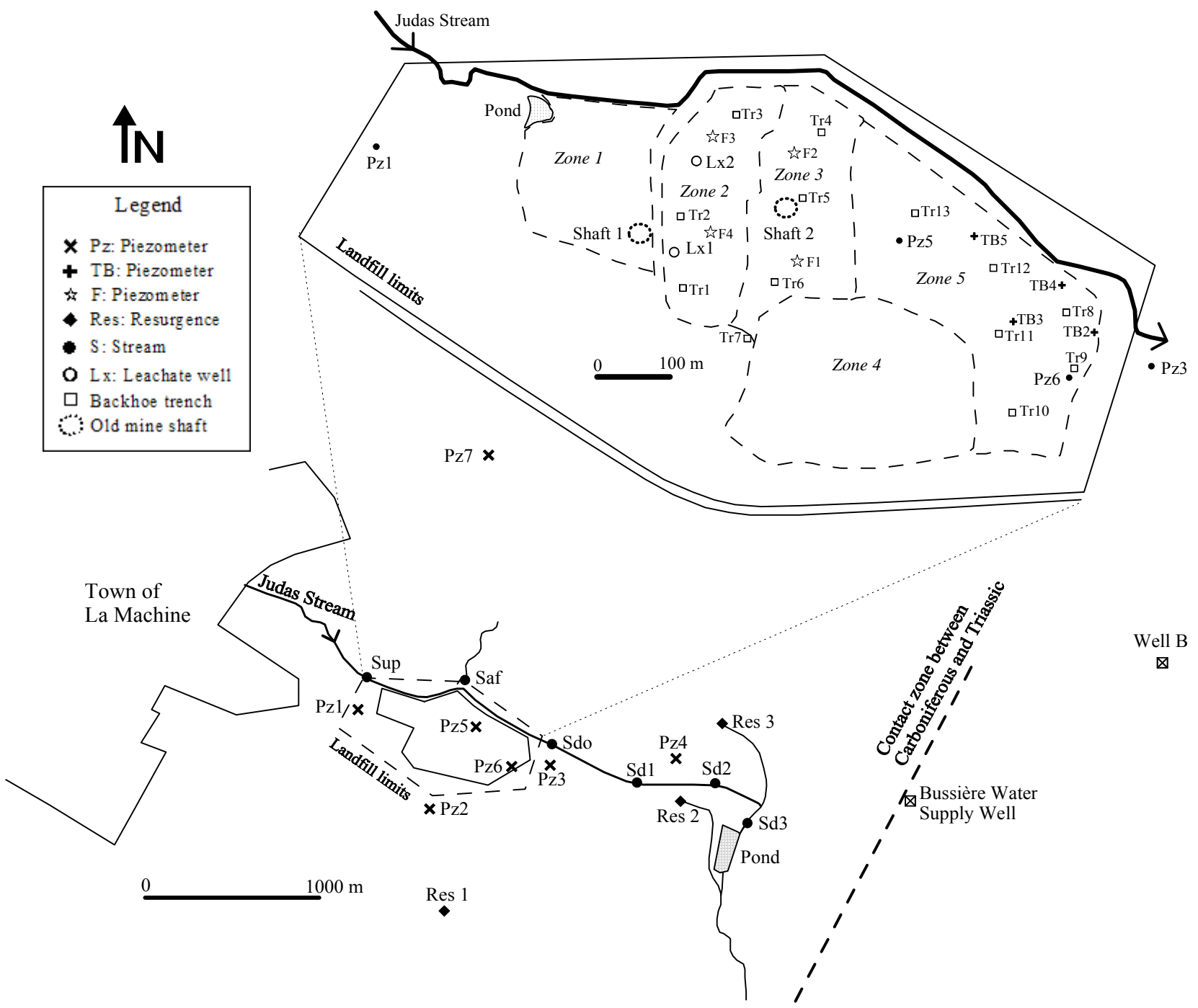

Fig. 1: Schematic of study area with locations of investigation and sampling points 


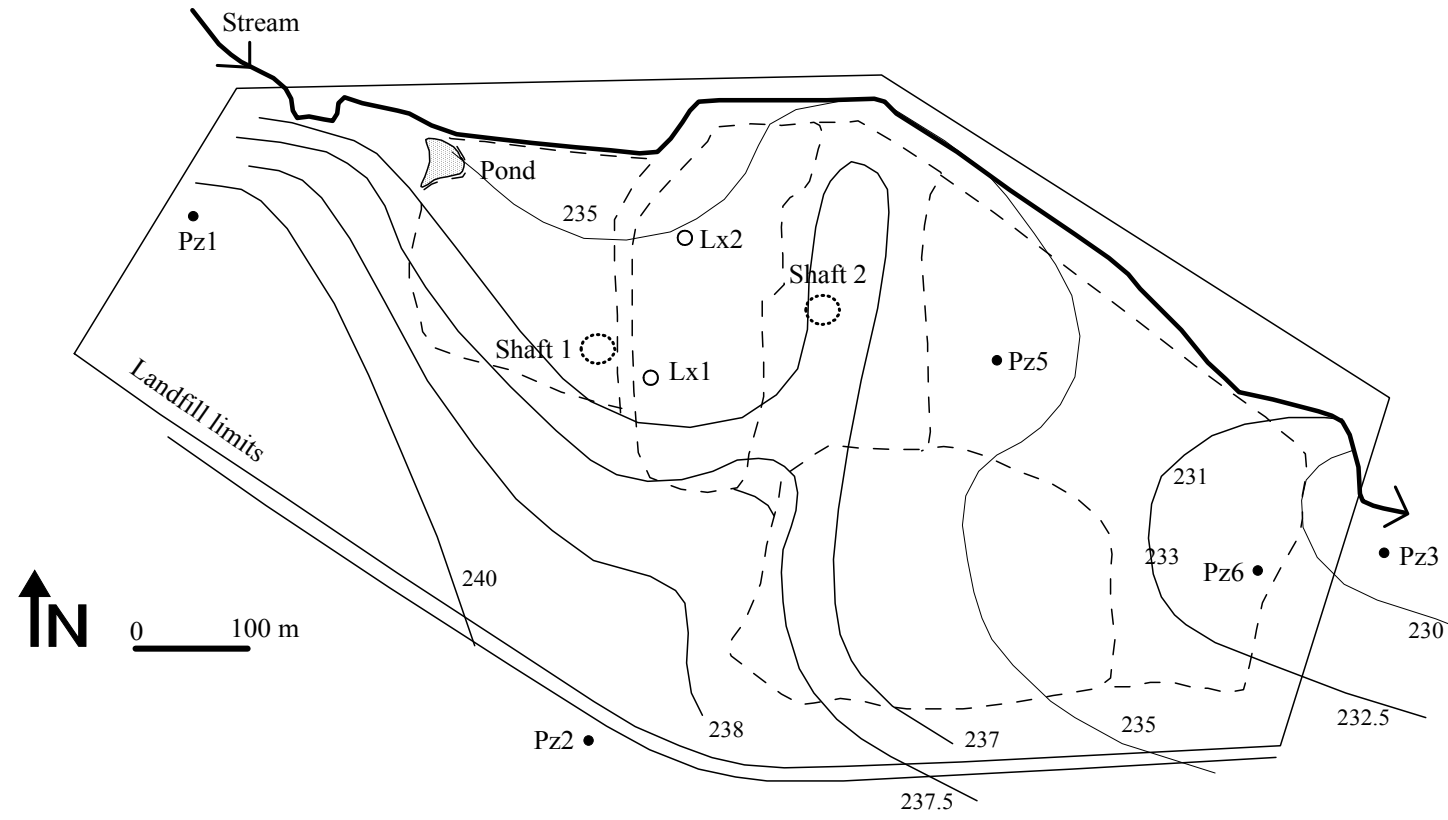

Fig. 2: La Machine landfill piezometric contours (March 2007; high phreatic level). Elevations in meters NGF

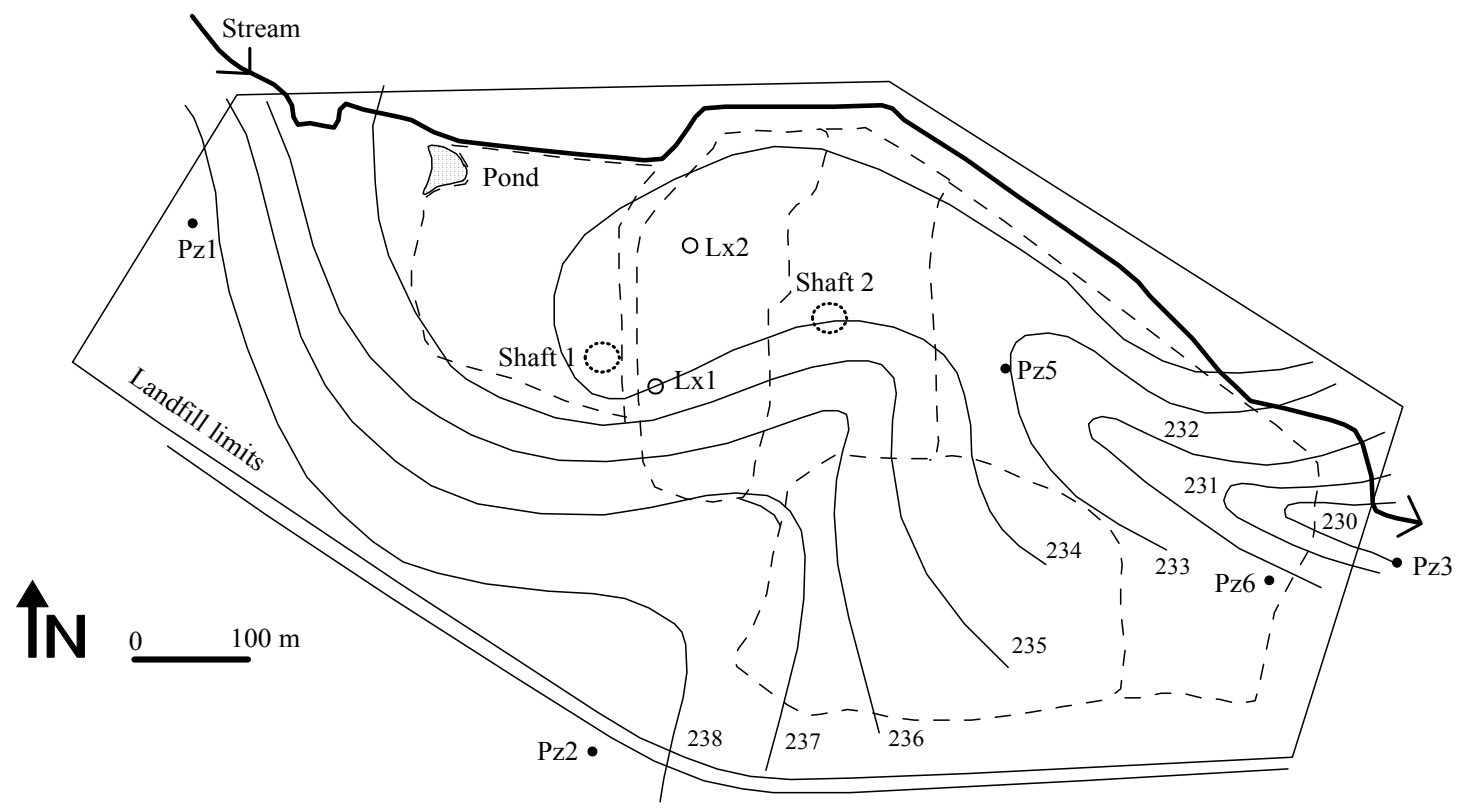

Fig. 3: La Machine landfill piezometric contours (September 2008; low phreatic level). Elevations in meters NGF 


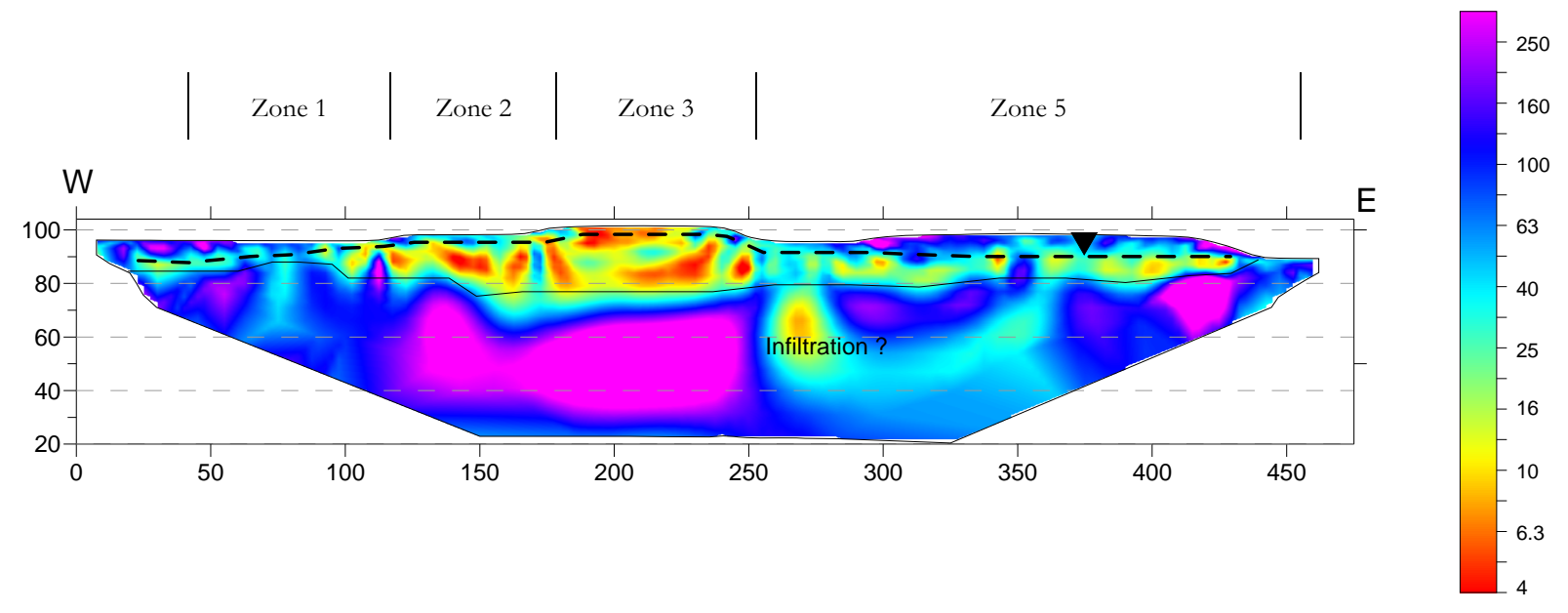

Fig. 4: La Machine landfill vertical electrical resistivity profile

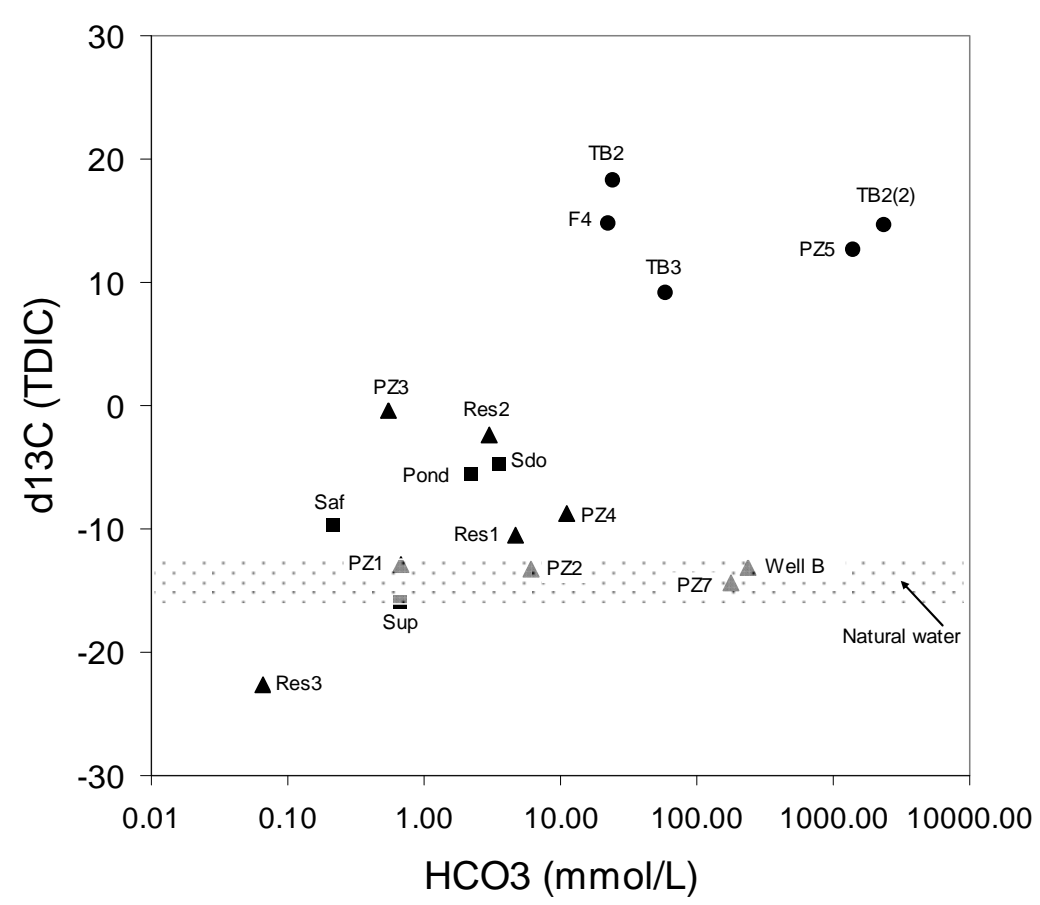

Fig. $5:{ }^{13} \mathrm{C} /{ }^{12} \mathrm{C}$ ratios versus bicarbonate concentrations in waters collected in the vicinity of the La Machine landfill 


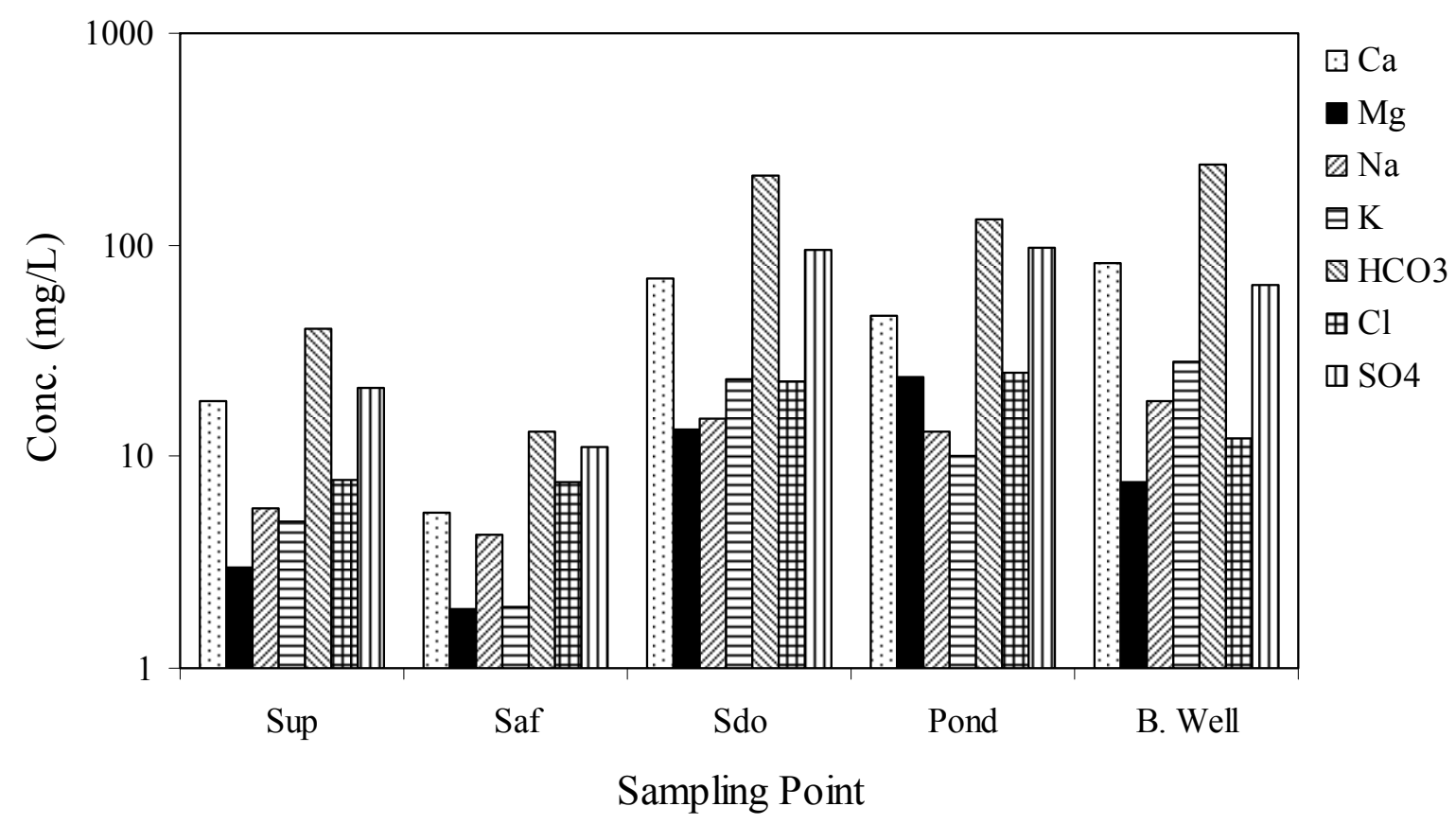

Fig. 6: Major ion concentrations in the Judas stream, the pond and the Bussière Well (see sampling points in Fig. 1)

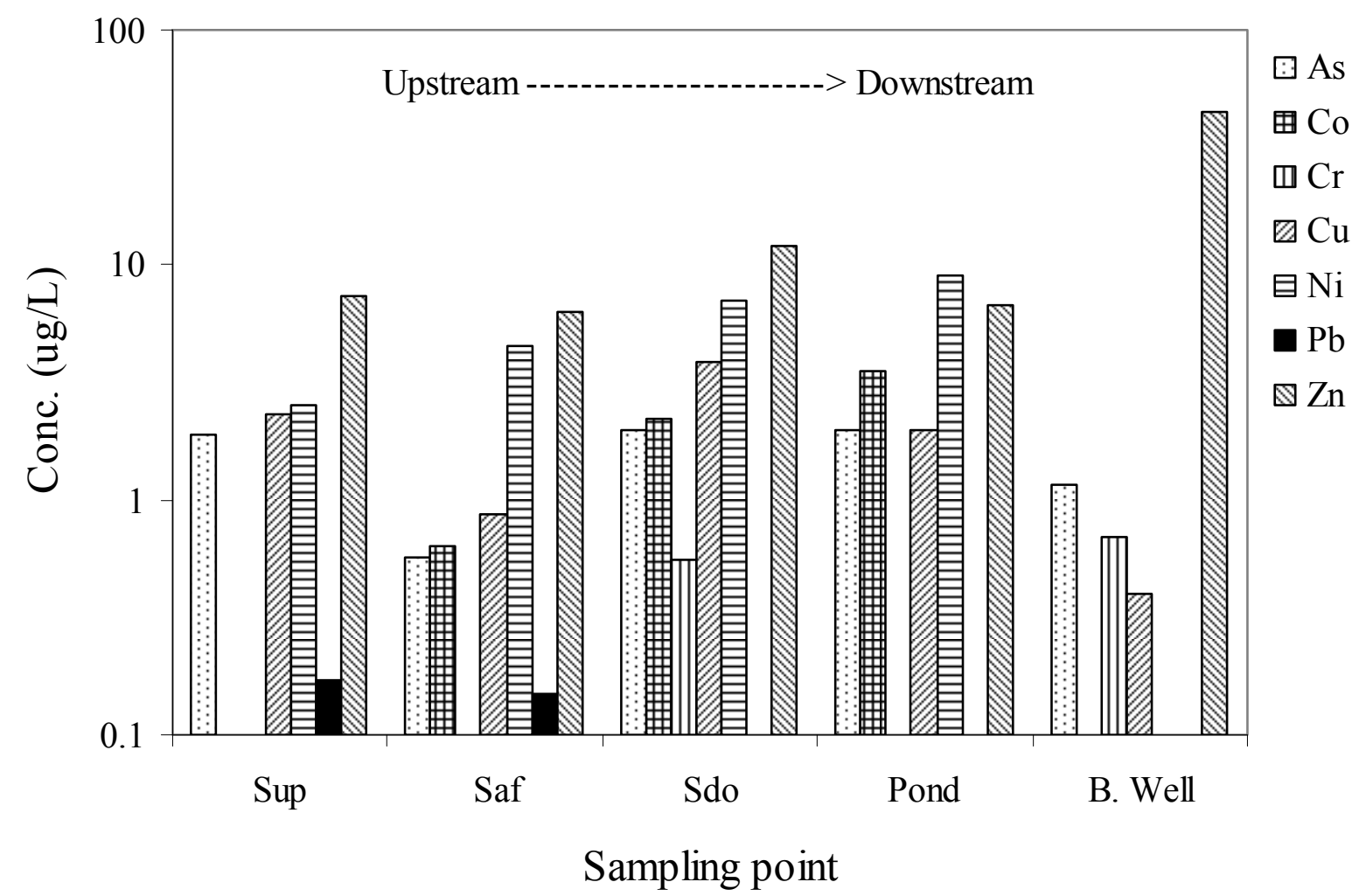

Fig. 7: Trace metal concentrations in the Judas stream, the pond and the Bussière Well (see sampling points in Fig. 1) 


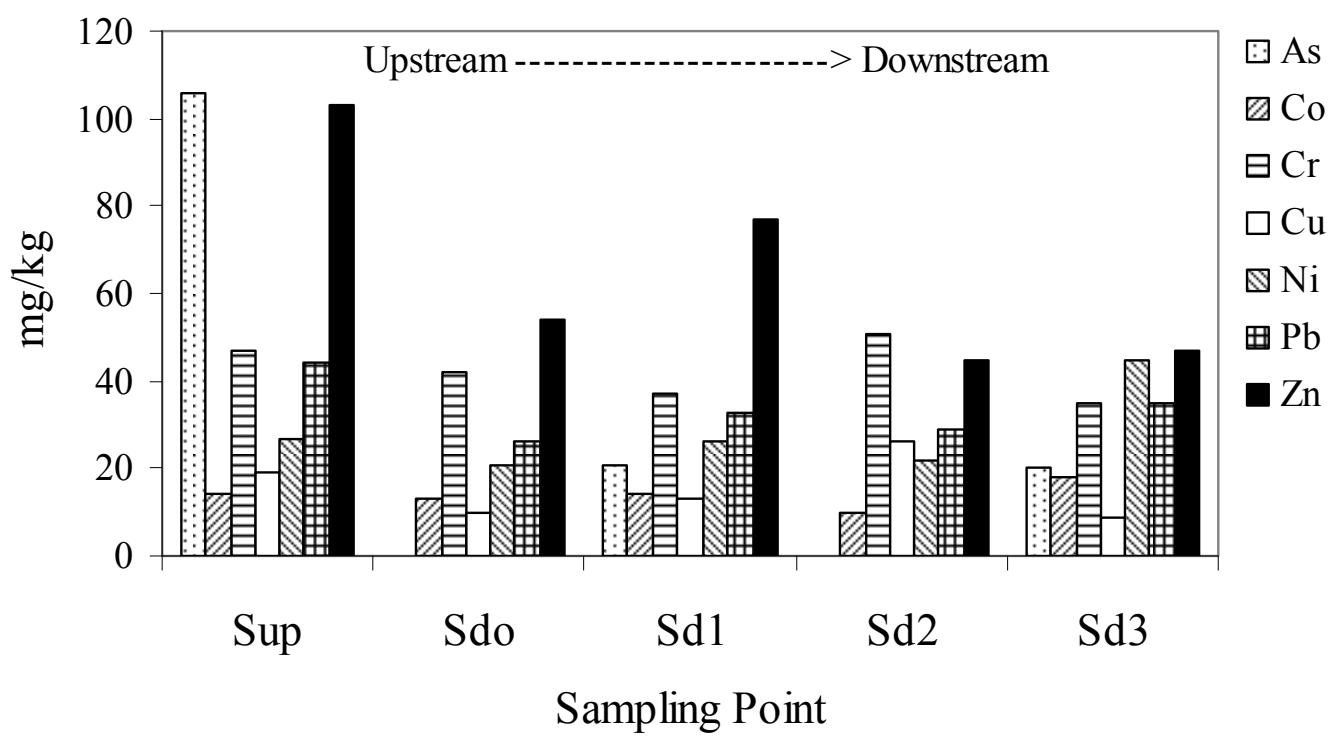

Fig. 8: Trace metal concentrations in sediments from the Judas Stream (see sampling points in Fig. 1) 


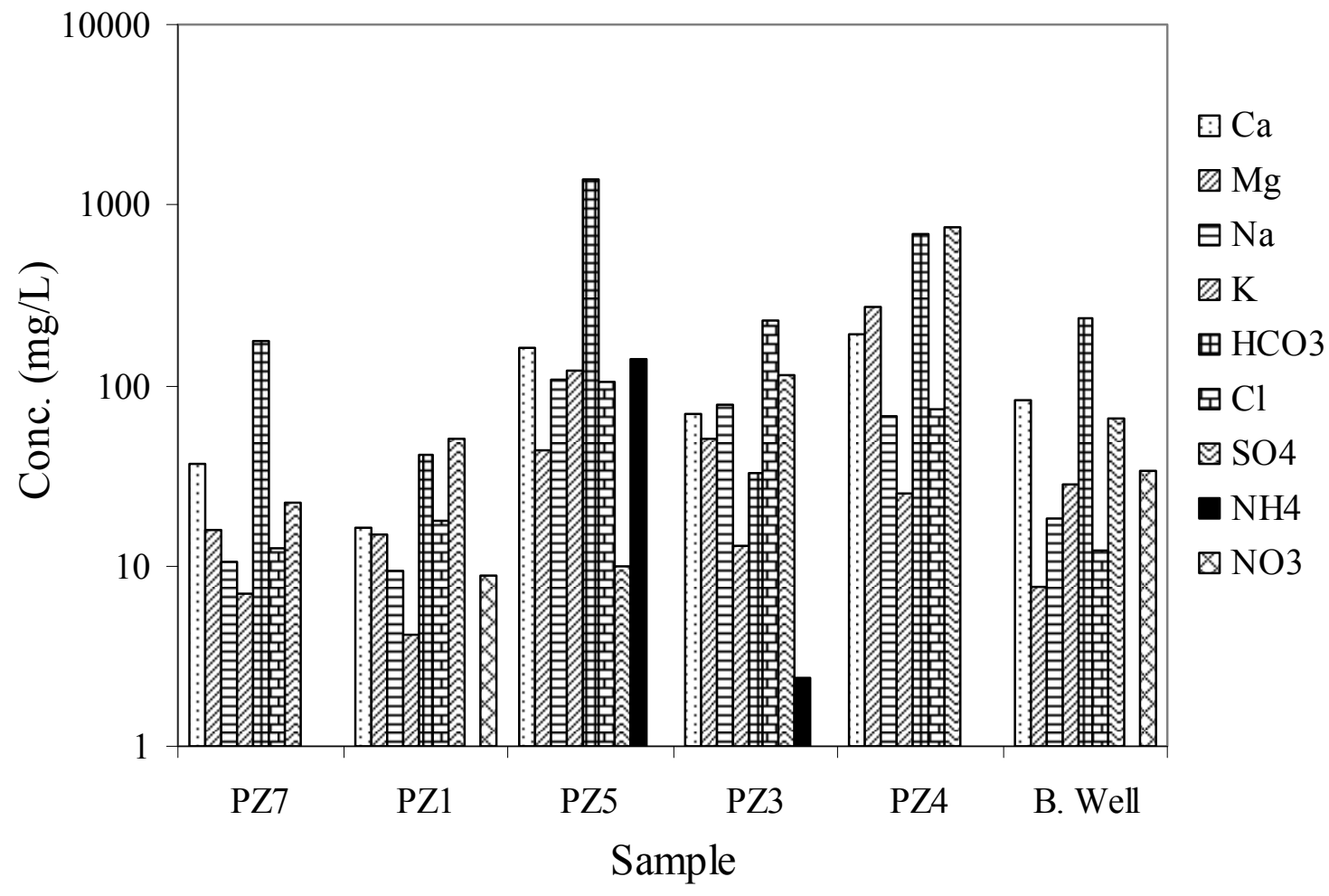

Fig. 9: Major ion concentrations in piezometers and the Bussière Well (see sampling points in Fig. 1)

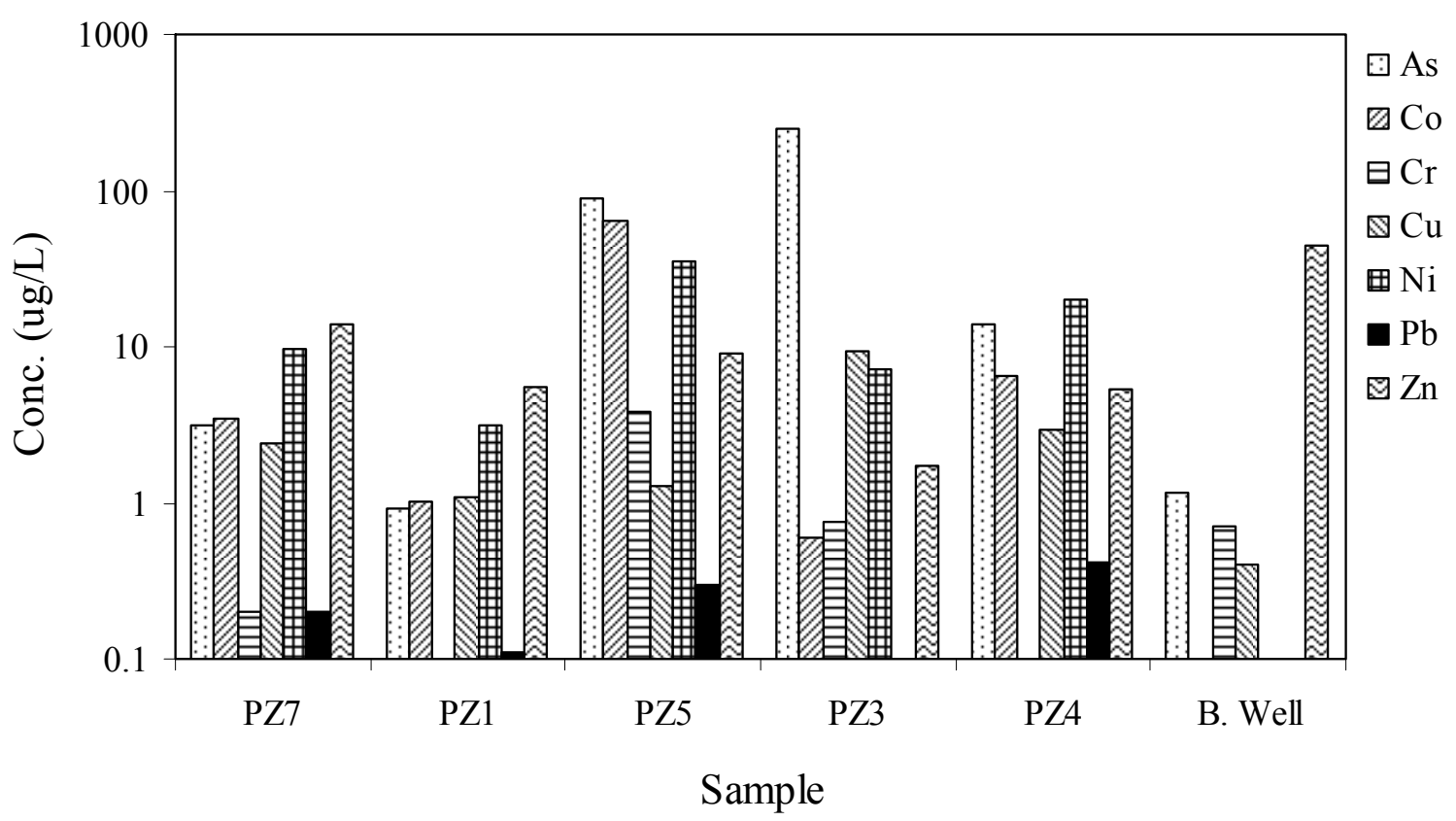

Fig. 10: Trace metal concentrations in piezometers and the Bussière Well (see sampling points in Fig. 1) 

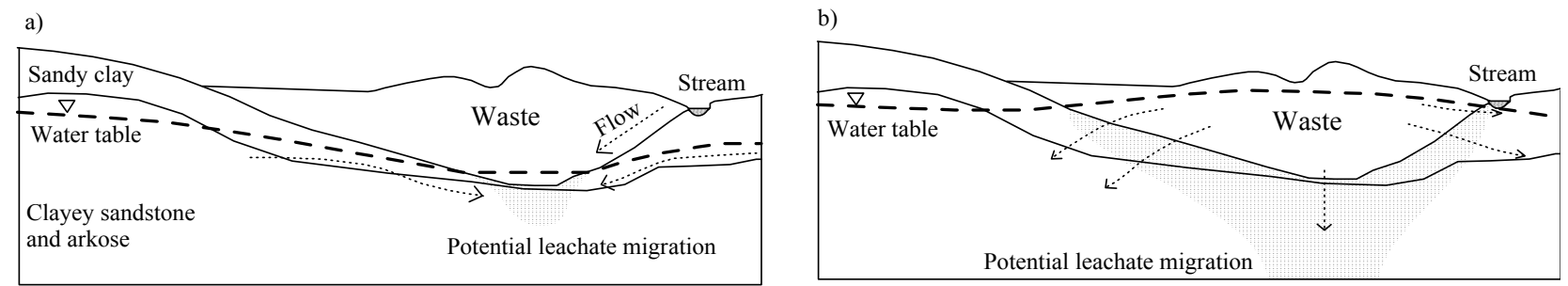

Fig. 11: Flow conceptual model for the La Machine landfill, a) low water level; b) high water level 